\title{
A Review of Public Speaking Coursebook: A Product of English Language Center Curriculum Research and Development
}

\author{
Elok Putri Nimasari ${ }^{1}$, Restu Mufanti ${ }^{2}$, Rohfin Andria Gestanti ${ }^{3}$ \\ Universitas Muhammadiyah Ponorogo, Jalan Budi Utomo, No 10, Ponorogo, East Java, \\ Indonesia ${ }^{1,2,3}$ \\ \{nimasari@umpo.ac.id ${ }^{1}$,restu.mufanti@umpo.ac.id²,rohfingestanti@umpo.ac.id ${ }^{3}$ \}
}

\begin{abstract}
English Language Center in Universitas Muhammadiyah Ponorogo is currently conducting a research and development of designing the best curriculum that correlates with students level and the university's pedagogical objectives. A previous internal research results imply that the Language Center should focus on two main courses: Standardized Test of Academic English Proficiency Test development and Public Speaking course project. Aligning to the prior research on Public Speaking curriculum development [1]-[3], this present study aims to deliver a final product of material development that is specifically designed for the first year students in Universitas Muhammadiyah Ponorogo. Document-based observation and analysis of Public Speaking's lesson plan is utilized as the key instrument of this research. Eight chapters of final product are presented. Furtermore, findings and discussion of the study are described qualitatively.
\end{abstract}

Keywords: English Language Center Curriculum, Public Speaking, Coursebook

\section{INTRODUCTION}

Curriculum is the center of learning that both formal and non-formal educational institutions should have. Generally speaking, curriculum provides a structured subject-matter and its teaching methodology that guide teachers and learners to well-receive required learning materials and experiences[4]-[7]. Therefore, learning goals can be successfuly achieved as expected.

The dynamic of English language center curriculum have been studied for years by many scholars[8]-[10]. Analyzing the need of learners and the specific targets that the institutions intend to accomplish is the primary stage to develop the best curriculum. A well-designed curriculum directly impacts how a teacher teaches and a student learns[11], [12]. In addition, to effectively succeed the institutions" aims, it is pivotal to have a strong fundamental principles that are based on intitutional policy, pedagogical goals and students' need analysis results[13], [14]. In summary, academic environment and conditions have a high critical influence into how the curriculum is designed.

Universitas Muhammadiyah Ponorogo, one of private universities in Indonesia, is recently evaluating what best practices that can bridge the importance of English competence for global demands and the students' capacity. According to the university policy, the students are 
expected to actively involve in the international forum delivering various ideas. It is because multidisiplinary fields from worldwide context are working together to reconcile current industrial revolution[1]. This underpinning purpose refers to students' speaking and listening competence. Although those two productive skills are required to succeed the standard from the university, critical thinking analysis competence is essential to shape the ability of conceptualizing, analyzing, applying, and synthesizing the information or ideas to the audience[15], [16]. From this perspective, public speaking course is selected as the suitable program to meet the institution expectation.

Several primary studies have been conducted to identify the needs of first year tertiary students and challenges in designing the curriculum of public speaking course in English Language Center of Universitas Muhammadiyah Ponorogo. Studies by Mufanti [17], Mufanti et al. [1], R.A. Gestanti, et al. [2] and E.P. Nimasari [18] verify that speaking anxiety is the first issue that prevents them to engage with people in group discussion forum. Another problem reported is instructors' obstacles in teaching public speaking materials[1], [17]. They found that it is highly demanding to develop practical materials that suit with students ' study background. The present study focuses on conducting a further research that fills the gap from the aformentioned research results. The objective of the study is developing a coursebook material based on lesson plan from public speaking program. Eight chapters of a coursebook final product are presented qualitatively.

\section{METHODOLOGY}

The study is classified as a qualitative research which addresses findings and discussion according to the data analysis descriptively. Two main instruments are used in the study. Literature reviews from the primary studies related to the research are gained as the underlying theory for the study[19]. Moreover, lesson plan of public speaking course program is employed as a center framework of the product since lesson plan is the central of material development[20]-[22]. Data of the study are collected from literature reviews and lesson plan's content. Thus, the raw material is organized using bottom-up approach. This approach is chosen as the best approach based on the results of the primary study[6], [23], [24].

\section{FINDINGS AND DISCUSSION}

\subsection{Public Speaking Course Framework}

Public speaking course program in English Language Center of Universitas Muhammadiyah Ponorogo is designed to develop speaking and listening competence of various critical ideas according to students' background of studies and to reduce students' anxiety and psychological barriers during their speech performance. The course consists of 16 meetings including learning class process, pre and post-test of speech. In the end of the program, students are required to be able deliver a six to eight-minute English public speaking that reflects innovative ideas in their disciplines. For instance, students of health science study program should be able to present their public speaking of cases related to the issues of health science. Therefore, students will have topics of speech depending on their filed of discipline. The following figure is the public speaking rubric descriptors to assess students' performance. 


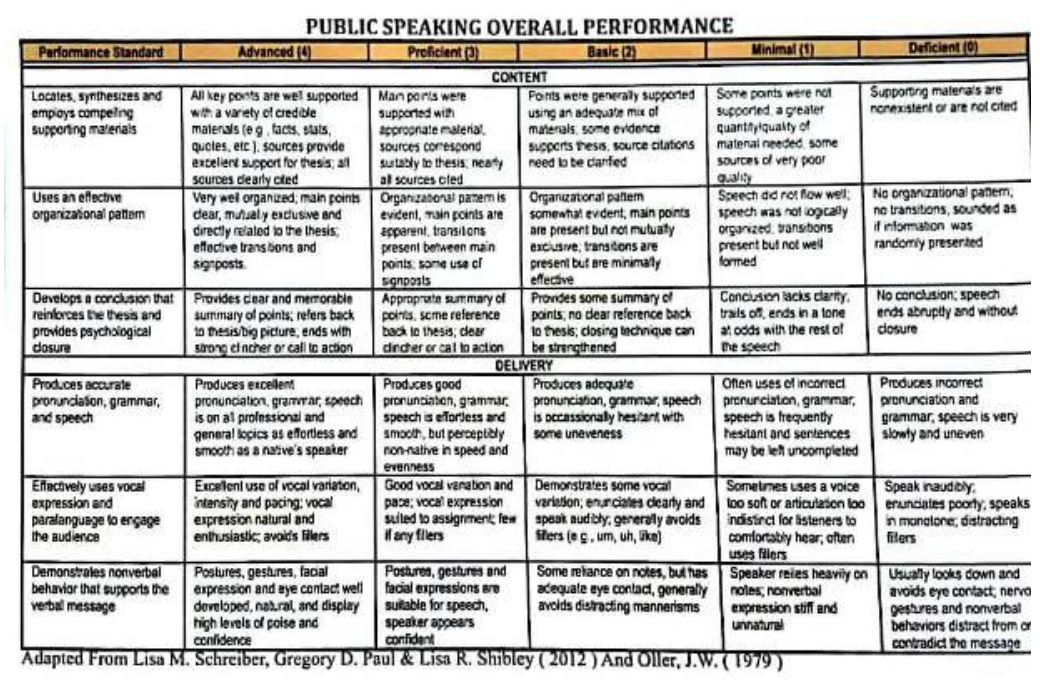

Fig. 1. Public Speaking's Score Rubric Descriptors

According to the results of a study by Mufanti, et al. [1], it is significant to study micro skills of public speaking before the students start to create their own speech. Some micro skills needed are, for instance, understanding the purpose of the speech, knowing the audience of the speech, and organizing important stages to give the best public speaking performance. Data from students' scores of pre-test performance also indicate that students are lack of information of how to prepare an interactive and interesting public speaking. The table below shows pre-test results.

\begin{tabular}{lcc}
\hline \multicolumn{1}{c}{ Faculty } & Pre-test & Category \\
\hline Islamic Faculty & 1.90 & Minimal \\
\hline Social and Political Science & 1.82 & Minimal \\
\hline Teacher training and Educational & 2.32 & Minimal \\
\hline Economic & 1.91 & Minimal \\
\hline Engineering & 1.88 & Minimal \\
\hline Health & 1.83 & Minimal \\
\hline Law & 1.60 & Minimal \\
\hline
\end{tabular}

Fig. 2. Sample Students' Pre-Test Average Scores

Considering the results of public speaking pre-test, it is necessary to teach students from bottom level or micro skills to the complex ones. From this result, public speaking's lesson plan is arranged using bottom-up teaching approach and is completed by various practical 
tasks that can encourage students to have a deeper-comprehension of the material[23]. Figure 3 displays sample lesson plan of public speaking course program.

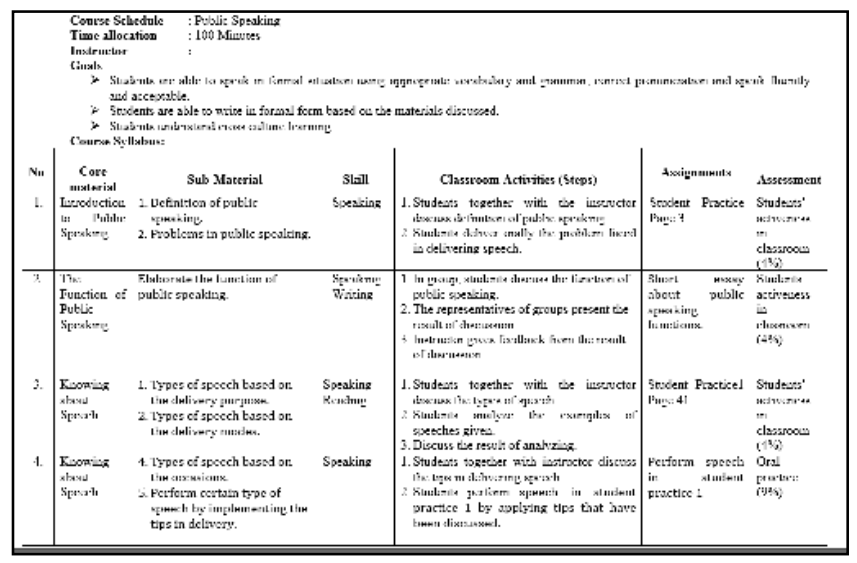

Fig. 3. Sample Lesson Plan of Public Speaking Course Program

The lesson plan's framework above are the basic structure to develop coursebook material. Each chapter consists of comprehensive information of micro skills under macro skills of public speaking: identifying major purposes, determining the types of speech, preparing the speech, designing a well-prepared speech, using appropriate speech language, and performing at the stage. This finding is in line with the theoretical framework reported by Leopold [16] that there are some micro skills of public speaking competence that is needed to master before developing one's own public speaking.

\subsection{Public Speaking Coursebook's Structure}

There are eight chapters developed in the coursebook: (I) Public Speaking, (II) The Function of Public Speaking, (III) Knowing about Your Speech, (IV) Preparing Your Speech, (V) Designing Your Speech, (VI) The Use of the Language, (VII) Delivering Your Speech, and (VIII) The Examples of Speech Text. Learning objectives of each chapter are explained in the beginning of the lesson to demonstrate what students are going to expect in the end of chapter. In addition, it also provides a clear frame for the students to focus on their attempts to succeed public speaking class. The following figures are the excerpts of coursebook material contained of learning objectives that previously stated in the lesson plan.
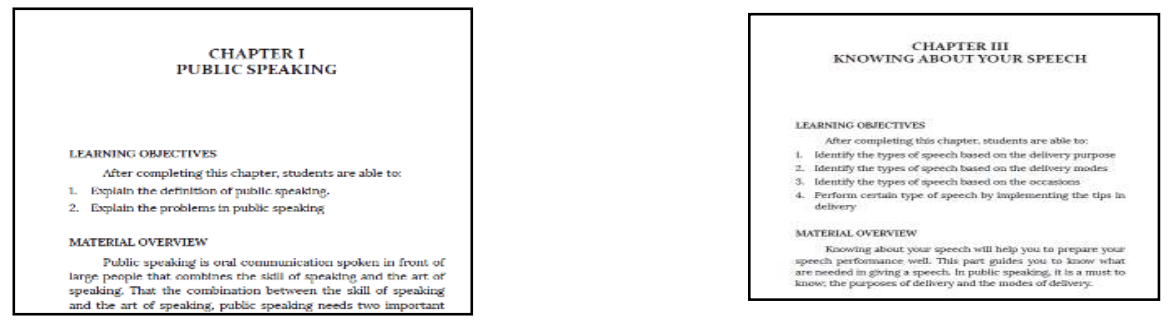

Fig. 4. Learning Objectives of Chapter I (p.1) and Chapter III (p.9) 
It can be seen in the figure 4 that in the chapter I, students are required to define the nature of public speaking activity and the issues that the speakers may encounter during the performance. As stated in the research methodology, that the coursebook development process, bottom-up approach is implemented. Therefore, students have a higher demand in the following chapters as described in the chapter III.

Apart from learning objectives, material overview is available for students to give them a general description of the lesson. In this part, they are facilitated an illustrative of micro skills they are going to learn in the chapter. Designed for academic tertiary context, the material is definitely supported by theoretical research framework from public speaking experts as can be reviewed in the figure 5 below.
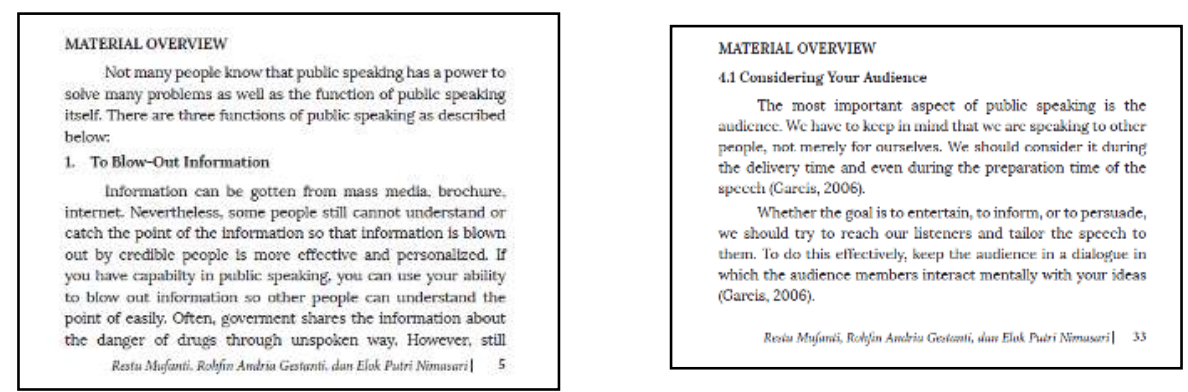

Fig. 5. Sample Material Overview of Chapter II (p.5) and Chapter IV (p.33)

Answering the gaps that the studies highlighted[1]-[3], the coursebook yields useful tips and advice in a particular layout to be easily learnt by the students. This guidance is given to help students' difficulties during their efforts in the public speaking course program. The tips are in a form of short table with a numbered list as presented in figure 6.
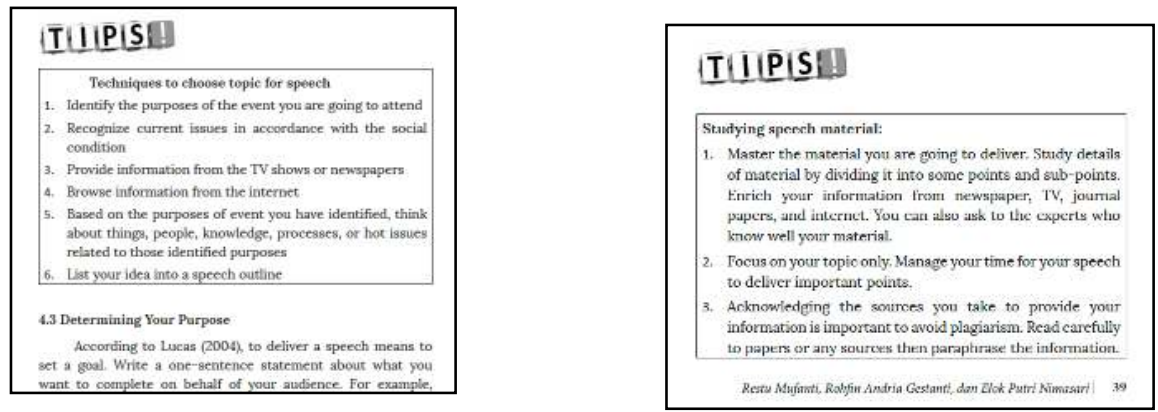

Fig. 6. Sample Useful Tips of Chapter IV (pp. 37 - 39) in the Coursebook

In addition to useful tips feature, there is also a similar attribute in the coursebook with a list of dos', don'ts and various recommended phrases for speech. These features can mentor the students to give a simple form of what should students do and avoid to vary their texts in front of many people[8], [10], [17]. 

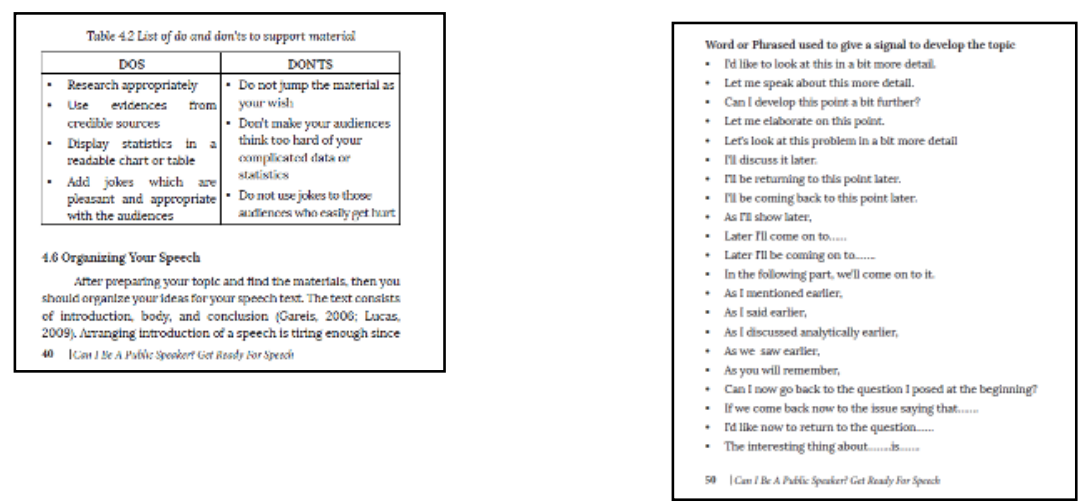

Fig. 7. Another Coursebook Feature to Simplify the Material

The last part of coursebook that promotes students' practical competence is summary of the lesson and students' practices. The practices are attached in the last of each chapter in the coursebook. This can be used to measure and evaluate students' comprehension of the lesson. Moreover, this tasks and authentic materials for public speaking topics facilitate an effective rehearsal to improve students' confident and ability performing a good public speaking in front of audience[3], [25].
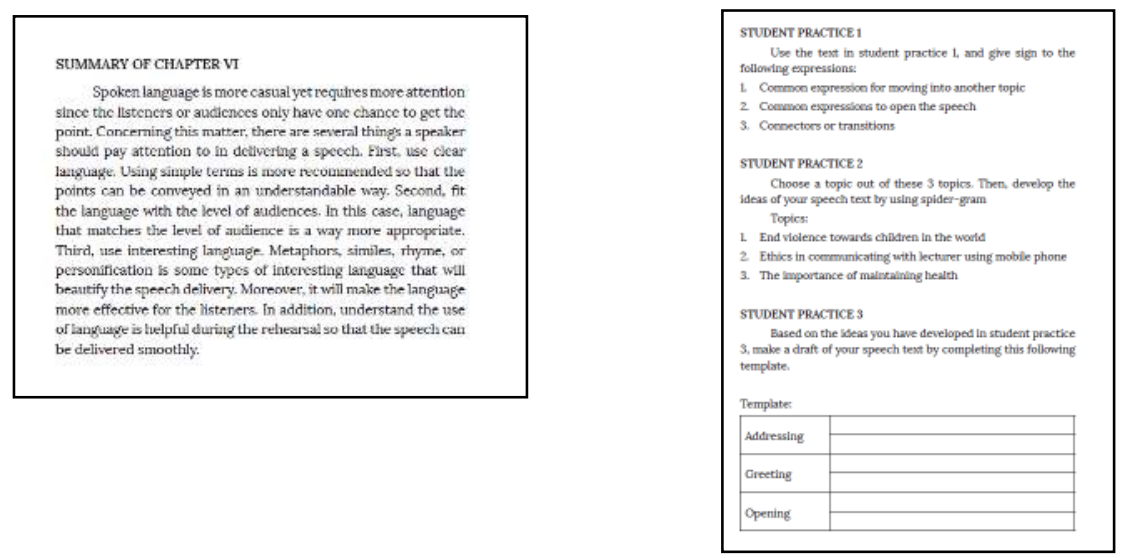

Fig. 8. Summary of Chapter (p.96) and Student Practices (p.86) in the coursebook

Linguistic aspect competence such as pronunciation and parts of speech is given following example texts that can be used for students. By having more example texts, students are intended to have more information, clearer insight, and decrease the chances that the fact or idea to be inappropriately applied to real-practical speech situations[6], [24]. 


\section{CONCLUSIONS}

The findings from the descriptive discussion respond to the research objective that focuses on presenting a final product of public speaking course book as a further examination from the previous studies. The eight chapters of coursebook and those features such as learning objective statements, material overview, useful tips, summary of lesson and student practices have been presented. The organization of the material uses bottom-up teaching approach in which students study from the most fundamental skill into the complex units[7], [15], [23], [24]. Bottom-up approach is applied to deal with existed situation which students have low understanding and competence in public speaking pre-test. Using lesson plan teaching framework, the material of the coursebook is designed accordingly[20]-[22].

The results of the study have implications for the innovation of English Language Teaching material and pedagogical curriculum research and development. At the individual level, the results of the study may inform a benefit value for those who need practical coursebook material with the same condition. At the organizational level, the results of this study indicate implications for positive educational and social change for improving practice across the country.

Apart from the implication of the study, the research limitation is addressed as recommendation for future research. While the study reports the result of public speaking coursebook material in the English certification program in Universitas Muhammadiyah Ponorogo, the study limits in quantitative research design. Further research require a more indepth analysis quantitatively of the effectiveness using the coursebook material correlated with other variables such as student's self-regulated learning and user experience.

\section{References}

[1] R. Mufanti et al., "PUBLIC SPEAKING INTENSIVE COURSE FOR STUDENTS OF NON- ENGLISH DEPARTMENT (A Study in English Language Centre)," Exposure, vol. 7, no. 2, pp. 161-178, 2018.

[2] R. A. Gestanti, E. P. Nimasari, and R. Mufanti, "Esp Issue in Indonesian Tertiary Context: What Students Need in Learning English," PUPIL Int. J. Teaching, Educ. Learn., vol. 3, no. 1, pp. 98-117, 2019.

[3] E. P. Nimasari, "English Material Development Based on Scientific Approach: a Content Analysis of 'When English Rings a Bell' Course Book," Kaji. Linguist. dan Sastra, vol. 1, no. 2, p. 105, 2017.

[4] M. R. Atai and F. Mazlum, "English language teaching curriculum in iran: Planning and practice," Curric. J., vol. 24, no. 3, pp. 389-411, 2013.

[5] A. Kostoulas and J. Stelma, "Understanding curriculum change in an ELT school in Greece," ELT J., vol. 71, no. 3, pp. 354-363, 2017.

[6] K. Fajii, "Exploration into the Effects of the Schema-Based," J. Pan-Pacific Assoc. Appl. Linguist., vol. 20, no. 1, pp. 75-94, 2016.

[7] M. L. Malebese, “A socially inclusive teaching strategy: A liberating pedagogy for responding to English literacy problems," vol. 39, no. 1, pp. 1-9, 2019.

[8] D. Irwansyah, "Teaching English at Indonesian Islamic Higher Education: An Epistemological Perspective," Din. Ilmu, vol. 18, no. 1, p. 1, 2018.

[9] E. N. Ogwu, "Comparative analysis of teacher trainee students' e- learning technology (ELT) readiness towards promoting global curriculum best practice," Educ. Res. Rev., vol. 11, no. 17, pp. 1679-1688, 2016.

[10] Y. Hery, "Teachers and students perceptions of communicative competence in English as 
a foreign language in Indonesia," Educ. Res. Rev., vol. 12, no. 17, pp. 867-883, 2017.

[11] Y. C. Kim and J. H. Jung, "Conceptualizing shadow curriculum: definition, features and the changing landscapes of learning cultures," J. Curric. Stud., vol. 51, no. 2, pp. 141$161,2019$.

[12] A. Wall and A. Leckie, "Curriculum Integration: An Overview," Curr. Issues Middle Lev. Educ., vol. 22, no. 1, pp. 36-40, 2007.

[13] P. Mahabeer, "Curriculum decision-makers on decolonising the teacher education curriculum," South African J. Educ., vol. 38, no. 4, pp. 1-13, 2019.

[14] I. Ashby, "Designing for Interdisciplinarity in Higher Education: Considerations for Instructional Designers," TechTrends, no. Holley 2017, pp. 202-208, 2018.

[15] J. Schneider, D. Börner, P. van Rosmalen, and M. Specht, "Presentation Trainer: what experts and computers can tell about your nonverbal communication," J. Comput. Assist. Learn., vol. 33, no. 2, pp. 164-177, 2017.

[16] L. Leopold, "Stunning statistics for persuasive speaking," Commun. Teach., vol. 31, no. 1, pp. 21-26, 2017.

[17] R. Mufanti, "The Supporting Factors And Barriers of Students Communicative Activities in a Speaking Class," 62nd TEFLIN Int. Conf., pp. 332-339, 2015.

[18] E. P. Nimasari, "AN ESP PROJECT WORK FOR ENGINEERING FACULTY: BOOSTING STUDENTS' AUTONOMY LEARNING," in PROCEEDINGS International Conference of 63 TEFLIN "Creativity and Innovation in Language Materials Development and Language Teaching Methodology in Asia and Beyond," 2017, pp. 553-557.

[19] D. Rubel and J. E. A. Okech, "Qualitative Research in Group Work: Status, Synergies, and Implementation,” J. Spec. Gr. Work, vol. 42, no. 1, pp. 54-86, 2017.

[20] T. Salagaram, "Benefits and challenges of lesson study: A case of teaching Physical Sciences in South Africa," South African J. Educ., vol. 39, no. 1, pp. 1-9, 2019.

[21] V. L. Akerson, K. Pongsanon, M. A. Park Rogers, I. Carter, and E. Galindo, "Exploring the Use of Lesson Study to Develop Elementary Preservice Teachers' Pedagogical Content Knowledge for Teaching Nature of Science," Int. J. Sci. Math. Educ., vol. 15, no. 2, pp. 293-312, 2017.

[22] W. Lim, J. W. Son, and D. J. Kim, "Understanding Preservice Teacher Skills to Construct Lesson Plans,” Int. J. Sci. Math. Educ., vol. 16, no. 3, pp. 519-538, 2018.

[23] G. Luera, S. Brunvand, and T. Marra, "Challenges and Rewards of Implementing ePortfolios Through a Bottom-Up Approach,” Int. J. ePortfolio, vol. 6, no. 2, pp. 127$137,2016$.

[24] A. N. Khuziakhmetov and G. V. Porchesku, "Teaching listening comprehension: Bottom-up approach,” Int. J. Environ. Sci. Educ., vol. 11, no. 8, pp. 1989-2001, 2016.

[25] E. P. Nimasari, R. A. Gestanti, and R. Mufanti, "What University-Students Believe About Plagiarism,” PEOPLE Int. J. Soc. Sci., vol. 4, no. 3, pp. 1912-1925, 2019. 
